\title{
La Revolución Cubana a través de la caricatura política en los periódicos El País y E1 Tiempo de Colombia 1958-1959*
}

\section{ANDRÉs Felipe GonZÁlez Bolaños}

Profesor de la Universidad del Valle - Sede Buga (Colombia). Correo electrónico: scout104@gmail.com. El autor es estudiante de doctorado en Historia Social de la Universidad Federal de Pará (Brasil). Entre sus publicaciones recientes tenemos: "la caricatura política en "El Relator", una fuente para la construcción histórica”. In: Anais XXVIII Simpósio Nacional de História, (Brasil: 2015). Entre sus temas de interés están Arte, Cultura, Religião e Linguagens.

Recibido: 2 de junio de 2016

Aprobado: 2 de marzo de 2017

Modificado: 17 de marzo de 2017

Artículo de investigación científica

DOI: http://dx.doi.org/10.15648/hc.32.2018.7

Este artículo forma parte del proyecto: "La Revolución Cubana a través de la caricatura política, en los diarios de publicación periódica de Brasil, Colombia y Argentina 1958-1962" financiado por el Coordenação de Aperfeiçoamento de Pessoal de Nível Superior (Capes) e o Programa de Pós-Graduação em História Social -PPHIST da Universidade Federal do Pará - UFPA (Brasil)

Esta publicación está bajo una licencia Creative Commons Reconocimiento-NoComercial 4.0 
La Revolución Cubana a través de la caricatura política en los periódicos E1 País y E1 Tiempo de Colombia 1958-1959

\title{
Resumen
}

Este artículo analiza cómo la Revolución Cubana fue representada en la caricatura política de los periódicos El País y El Tiempo de Colombia, entre 1958 y 1959, identificando los temas, metáforas, símbolos y figuras más recurrentes utilizadas por los caricaturistas para influenciar en la opinión pública y legitimar los discursos políticos promovidos por estos diarios. Además de percibir los cambios sufridos por las caricaturas con el paso del tiempo, que llevaron a una deconstrucción simbólica de la imagen de Fidel Castro y la Revolución.

Palabras clave: Revolución Cubana, opinión pública, caricatura política, periódicos colombianos.

\section{The Cuban Revolution through political cartoons of E1 Pais and E1 Tiempo newspapers in Colombia 1958-1959}

\begin{abstract}
This article analyses how the Cuban Revolution was represented in the political cartoons of El Pais and El Tiempo newspapers from Colombia, between 1958 and 1959, identifying the most recurring themes, metaphors, symbols and figures used by the caricaturists with the purpose of influencing on the public opinion and legitimizing the political discourses promoted by these newspapers. In addition to perceiving the changes reflected by the cartoons with the time, which led to a symbolic deconstruction of Fidel Castro and the Revolution images.
\end{abstract}

Key words: Cuban Revolution, public opinion, political cartoon, colombian newspapers

\section{A Revolução Cubana através da caricatura política nos jornais El País e El Tem- po de Colômbia 1958-1959}

\section{Resumo}

Este artigo analisa como a Revolução Cubana foi representada na caricatura política dos jornais El País e El Tempo de Colômbia, entre 1958 e 1959, identificando os temas, metá- 
foras, símbolos e figuras mais recorrentes utilizadas pelos caricaturistas para influenciar na opinião pública e legitimar os discursos políticos promovidos por estes diários. Além de perceber as mudanças sofridas pelas caricaturas com o passo do tempo, que levaram a uma desconstrucción simbólica da imagem de Fidel Castro e a Revolução.

Palavras-chave: Revolução Cubana, opinião pública, caricatura política, jornais colombianos.

La Révolution Cubaine à travers la caricature politique dans les journaux E1 País et E1 Tiempo de Colombie 1958-1959

\section{Résumé}

Cet article fait l'analyse de comment la Révolution Cubaine a été représentée dans la caricature politique des journaux El País et El Tiempo de Colombie, dans les années 1958 et 1959, identifiant les sujets, les métaphores, les symboles et les figures plus récurrentes utilisées par les caricaturistes, pour influencer l'opinion publique et légitimer les discours politiques promus par ces journaux. En plus de percevoir les changements subis par les caricaturistes à travers le temps, ce qui a provoqué une déconstruction symbolique de l’image de Fidel Castro et de celle de la Révolution.

Mots clés: Révolution Cubaine, opinion publique, caricature politique, journaux colombiens.

\section{INTRODUCCIÓN}

El 1 de enero de 2016 se cumplieron 57 años del triunfo de la Revolución Cubana, un acontecimiento que marcó la historia latinoamericana, y que después de medio siglo permanece presente en la memoria de las generaciones que han crecido con ella y otras que han escuchado hablar de ella. Muchos aún recuerdan, cómo un grupo de barbudos con fusil en mano y vestidos de uniforme verde oliva, lucharon desde la legendaria Sierra Maestra.

Estos hombres se enfrentaron a la dictadura de Fulgencio Batista, el intervencionismo extranjero y la miseria sembrada en su pueblo desde los 
tiempos de la Colonia. Ideales nobles que darían la vuelta al mundo a finales de la década de los cincuenta, creando seguidores y opositores al mismo tiempo. Los "barbudos de Fidel", como eran nombrados por la prensa, se dieron a conocer gracias al papel que jugaron los medios de comunicación, como lo señala la investigadora Patricia Calvo González, ya que la Revolución Cubana no dependió exclusivamente del apoyo logístico y armamentístico, sino también con la mejor arma que podía contar en ese momento: "la opinión pública"1.

En este sentido, la prensa escrita jugaría un papel importante, puesto que en sus páginas se consignaría una gran variedad de adjetivos, negativos y positivos para representar la Revolución Cubana. Entre los calificativos encontrados se destacan los siguientes: terroristas, rebeldes, revoltosos, bandidos, héroes, tiranos, salvadores del pueblo, barbudos... etc. Los cuales fueron reforzados con un lenguaje visual a través de las caricaturas, ilustraciones y fotografías que acompañaron este acontecimiento de grandes proporciones para la historia de Latinoamérica.

Por lo tanto, el objetivo general de este artículo es analizar cómo se representaba $^{2}$ la Revolución Cubana en uno de estos lenguajes visuales: la caricatura política ${ }^{3}$, especialmente, en los periódicos colombianos El País

1 Patricia Calvo González, "El proceso revolucionario cubano desde la óptica de la dimensión pública: el papel de los medios de comunicación”. XVI Encuentro de Latinoamericanistas Españoles. Congreso Internacional (España: Universidad de Santiago de Compostela, septiembre de 2010), 1557 1576.

2 Chartier describe la representación como "un instrumento de un conocimiento mediato que hace ver un objeto ausente al sustituirlo por una "imagen" capaz de volverlo a la memoria". Un ejemplo de esto, serían los maniquíes de cera o madera que se colocaban encima del ataúd durante los funerales de los hombres importantes de una sociedad. De igual forma, existe otro tipo de representación, donde las imágenes juegan un papel diferente en el caso de la relación simbólica que consiste en "la representación de algo moral mediante las imágenes o las propiedades de las cosas naturales". Un ejemplo de esto, lo podemos ver cuando se utiliza al león como símbolo de lealtad y la hiena como de traición. Este tipo de representación es empleado con mucha frecuencia en las caricaturas políticas encontradas en los periódicos investigados. Ver: Roger Chartier, El mundo como representación. Estudios sobre historia cultural (España: Gedisa, 2005), 58.

3 Darío Acevedo Carmona identifica una serie de características adecuadas para tener presente en el momento de identificar y estudiar la caricatura política. La primera de estas cualidades consiste en "la deformación o exageración de los rasgos de los personajes"; la segunda, se encarga de "los personajes, situaciones, lugares y hechos que figuran en los dibujos" los cuales son identificables para el lector; la tercera, se inspira en "hechos de la actualidad política doméstica e internacional"; la cuarta, 
y El Tiempo entre 1958 y 1959. Además de definir qué papel jugó la caricatura política en la construcción de una opinión pública ${ }^{4}$ respecto a los acontecimientos que se desarrollaban en Cuba. De igual forma, se suscribe en una línea de reflexión teórica que reconoce las imágenes no solo con un documento histórico que permite entender el contexto social ${ }^{5}$ sino también como protagonista de la historia.

\section{El País y $E_{L}$ Tiempo, entre la PRENSA y el PODER POlítico}

El diario El País nace en la ciudad de Santiago de Cali, el domingo 23 de abril de 1950 en una antigua casa situada a una cuadra de la Plaza de Caycedo, la cual era propiedad del señor Álvaro Lloreda Caicedo ${ }^{6}$. Desde su fundación, durante una de las épocas más difíciles de la historia de Colombia, este diario destinó sus esfuerzos no solo al registro cotidiano de las noticias regionales, nacionales e internacionales, sino también, al apoyo incondicional del pensamiento político conservador. En la actualidad este diario goza de gran popularidad en el departamento del Valle del Cauca.

Por otra parte, el periódico El Tiempo surgió el 30 de enero de 1911, cuando transcurría el gobierno conservador de Carlos Eugenio Restrepo. En

"las historias, imágenes, metáforas y alegorías que se constituyen en síntesis o simplificaciones de una situación o personaje, dicen mucho en muy pocos trazos o líneas"; la quinta, donde existe dislocación o trastrocamiento de hechos o de cosas dichas y responsabilidades; la sexta, la que tiende a señalar cualidades humorísticas y artísticas, particularmente las del dibujo, y por último las que constituyen armas de ataque o de defensa". Ver: Darío Acevedo Carmona, "Política y caudillos colombianos en la caricatura editorial, 1920-1950”, Revista Historia y Sociedad No. 17 (2009): 237-282.

4 Según Habermas, la opinión pública es la función crítica que realizan los ciudadanos que se reúnen libremente en la esfera pública, sin presiones y con las garantías de poder manifestar su opinión de acuerdo a sus intereses. Surge en el ámbito de la publicidad burguesa pero acaba por afectar al conjunto de los ciudadanos, cuanto menos a los ciudadanos ilustrados que toman una postura respecto al Estado. Ver: Jürgen Habermas, Historia crítica de la opinión pública (México: Gili, 1994).

5 Con base en los principios de la historia cultural, Peter Burke centra su interés en analizar las imágenes como creaciones que forman parte de un contexto social. Así las “imágenes constituyen un testimonio del ordenamiento social del pasado y sobre todo de las formas de pensar y de ver las cosas en tiempos pretéritos". Peter Burke, Visto y no visto. El uso de la imagen como documento histórico (Barcelona: Crítica, 2001).

6 Álvaro Lloreda Caicedo (1903-1985) fue un industrial colombiano, editor de periódicos y político. En 1949, Lloreda junto con sus hermanos Mario y Alfredo, fundó el diario El País. Véase: Decreto No. 0313 del Gobierno Municipal de Santiago de Cali, "por el cual se exalta una personalidad y se lamenta su sensible fallecimiento” (Cali, 1985). ftp://ftp.cali.gov.co/DECRETOS/1985/DECRETO0313ABRIL1985.pdf (fecha de consulta: 7 de mayo de 2015). 
la ciudad de Bogotá, de la mano de Alfonso Villegas Restrepo, quien fue su propietario durante dos años, para luego vendérselo a Eduardo Santos Montejo, expresidente de Colombia (1938-1942).

Durante su paso por el periódico, Eduardo Santos fue su director por 25 años, período suficiente para definirlo a través de sus editoriales como un diario político de fuertes ideales y principios liberales. Esta publicación ha registrado por más de un siglo los acontecimientos de la historia de Colombia y el mundo como: "Masacre en las Bananeras, la depresión económica de los años 30, la Guerra contra el Perú, la II Guerra Mundial, la tragedia de Armero, el holocausto del Palacio de Justicia, la guerra del narcotráfico, el conflicto de guerrilleros y paramilitares"”.

A la vez que registró la historia, también le correspondió vivir parte de ella cuando el 4 de agosto de 1955, el periódico fue clausurado por el general Rojas Pinilla. Durante la noche del 3 de agosto, las fuerzas armadas ocuparon el edificio donde funcionaba este diario ${ }^{8}$. A partir de entonces permaneció cerrado por 24 meses y 4 días, cuando reanuda su edición el sábado 8 de junio de 1957 como homenaje a los estudiantes que cayeron sacrificados en las calles de Bogotá el 8 y 9 de junio de 1954. El ejemplar que circuló ese día, se titulaba "Abriendo las puertas de El Tiempo" acompañado de la siguiente frase: "Quiera Dios permitir que El Tiempo sea siempre digno de la tarea que lo espera, y de la confianza nacional que lo rodea y estimula"'.

En algunos círculos políticos, se solía decir que el periódico El Tiempo ejercía una influencia significativa en la opinión pública de los colombianos, y que sus páginas marcaban la línea política del país, tanto así, que "ponía y quitaba ministros y presidentes". Después de celebrar su centenario, aún continúa influenciando muchas de las opiniones que circulan en la esfera 
pública y política ${ }^{10}$. En la actualidad, el diario ya no le pertenece completamente a la familia Santos, dado que el 30 de octubre de 2006, la mitad de sus acciones son compradas por el grupo español Planeta ${ }^{11}$.

Los diarios El País y El Tiempo, al igual que otros diarios colombianos, fueron creados por dirigentes políticos influyentes de la época, un hecho no muy distante de la realidad por la que pasaba la prensa nacional de aquel entonces. Un ejemplo fiel de esta tendencia, fue la empresa emprendida por Rafael Uribe Uribe, cuando crea en 1914 El Liberal, tal como lo señala Vallejo Mejía, "se fundan para lo que se fundan todos los periódicos, de antes, de ahora y acaso del futuro: para defender una ideología"12.

De esta forma los periódicos y todos los elementos que los constituyen como las caricaturas, texto y fotografías, son parte fundamental de una corriente de pensamiento que permite moldear las ideas de sus lectores y depositar una visión del mundo, una representación, como señala Roger Chartier, "describen la sociedad tal como (sus formuladores) piensan que ella es, o como gustarían que fuese" ${ }^{\prime 13}$.

\section{UNA REVOLUCIÓN INSPIRADORA}

La Revolución Cubana fue uno de los acontecimientos más significativos del siglo XX en la lucha sociopolítica latinoamericana, y su desarrollo se encuentra envuelto entre logros, desilusiones, leyendas e historias sorprendentes puesto que un reducido grupo de hombres con ayuda del pueblo, retó a un gobierno tirano y consiguió vencerlo desde una pequeña porción de tierra en la Sierra Maestra, teniendo como resultado la libertad com-

10 Salud Hernández Mora, "El Tiempo, principal diario de Colombia".

11 Gina Paola Collazos González, Diseño editorial como expresión y afirmación de la ideología política, social y cultural. Casos de estudio: La Nación de Argentina y El Tiempo de Colombia (Tesis de Maestría en Diseño, Universidad de Palermo. Facultad de Diseño y Comunicación, 2011), 53.

12 Maryluz Vallejo Mejía, A plomo herido, una crónica del periodismo en Colombia 1880-1980 (Bogotá: Editorial Planeta, 2006).

13 Roger Chartier, A historia cultural: entre prática e representações (Rio de Janeiro: Difel, Bertrand Brasil, 1990). 
pleta del dominio capitalista americano ${ }^{14}$. Ernesto Guevara muy conocido como el "Che" decía:

"La Revolución Cubana abre una etapa histórica en escala continental, marcada por la "actualidad de la revolución" en América Latina y caracterizada por tres elementos básicos: a) crisis de dominación política y equilibrio inestable entre las clases; b) ascenso de la lucha popular y posibilidad de traducir estas luchas entre enfrentamiento político-militar; c) declive relativo del potencial económico y militar de Estados Unidos”15.

Esta revolución es el resultado de una necesidad histórica del pueblo cubano, que en contra de todo pronóstico consiguió ganarle la guerra al régimen corrupto de aquel momento y a la mayor potencia imperialista que se encontraba a tan solo unas pocas millas de su costa. Un logro, que es atribuido al pueblo de aquel entonces y que su máximo líder Fidel Castro reconoció en un discurso pronunciado el 8 de enero de 1959, durante su entrada triunfal a La Habana: "Pero, ¿quién ganó la guerra? El pueblo ganó la guerra. Esta guerra no la ganó nadie más que el pueblo. Y lo digo por si alguien cree que la ganó él, o por si alguna tropa cree que la ganó ella. Y por tanto, antes que nada, el pueblo"16.

Por lo tanto, la Revolución Cubana fue un proceso histórico de lucha social librado por el pueblo cubano contra la injusticia, la desigualdad, la corrupción y el intervencionismo extranjero, desde el proceso frustrado de independencia ocurrido a finales del siglo XIX, hasta los primeros días de

14 La confrontación Cuba-Estados Unidos ha estado provocada por la pretensión norteamericana de mantener a Cuba bajo su dominio neocolonial. El conflicto no nació con el triunfo de la Revolución, solo se agudizó cuando el pueblo de Cuba logró romper las cadenas que lo ataban al imperialismo yanqui y decidir su propio destino socialista. Ver: Arnaldo Silva León, Breve historia de la Revolución Cubana (La Habana: Editorial de Ciencias Sociales-Instituto Cubano del Libro, 2003).

15 Manolo Monereo Pérez, Che Guevara: Contribuição ao pensamento revolucionário (São Paulo: Expressão Popular, 2001), 128.

16 Adolfo Sánchez Rebolledo, Fidel Castro: la Revolución Cubana 1953-1962, compilación de documentos y discursos de 1953 a 1962 (México: Ediciones ERA, S.A., 1972) 141. En: Arnaldo Silva León, Breve historia de la Revolución Cubana. 
1959 cuando triunfa el liderazgo asumido por el Movimiento 26 de Julio en esta lucha ${ }^{17}$.

Este liderazgo iniciaría un 2 de diciembre de 1956, después del difícil y fallido desembarco de los tripulantes del Granma, en las playas de las Coloradas donde Fidel Castro consiguió reunir solo 20 sobrevivientes de los 80 expedicionarios que lo acompañaban. A esta nueva empresa se sumarían algunos campesinos que tras la llegada de este grupo se habían llenado de espíritu revolucionario, dando inicio a la lucha guerrillera en las montañas de la Sierra Maestra ${ }^{18}$. Tal como lo atestigua Fidel Castro, en una entrevista realizada por Andrew St. George, cuando aún no se había consolidado la revolución:

"El 2 de diciembre de 1956, al amanecer, rifle en mano, Fidel Castro a la cabeza de su "ejército civil", desembarcó en la costa suroriental de la Provincia de Oriente. El viaje marítimo - refiere Fidel Castro- duró ocho días. Todo lo que podía salir mal, mal salió. La embarcación hizo agua, falló la bomba, y el radio no sirvió para nada. Uno de los motores diésel de la nave se averió y fue imposible repararlo. Ya en aguas cubanas dimos con cañonero que abrió fuego contra nosotros. Por radio llamó bombarderos, que acudieron inmediatamente. Por solo cinco minutos escapamos de su ataque. Ya en la playa, caímos en una emboscada del ejército. Tuvimos que retirarnos al monte. Pero aquello no importó nada a nadie. Estábamos en nuestro país, éramos libres, y a donde fuéramos la libertad iba con nosotros..."19.

17 Como en el resto de Hispanoamérica, los primeros movimientos anticolonialistas se vertebraron en el período de 1808 a 1826, cuando no se alcanzó la emancipación de Cuba por una confluencia de factores adversos, entre ellos, el auge que entonces experimentaba la plantación azucarera de base esclavista y la oposición de Estados Unidos, que aspiraba a heredar de España su dominio sobre la mayor de las Antillas. Véase: Sergio Guerra y Alejo Maldonado, Historia de la Revolución Cubana (Navarra: Edición de Txalaparta, 2009).

18 Miguel Leal Cruz, "Cuba en la prensa canaria 1934-1962, antecedentes y revolución”" (Tesis doctoral en Ciencias de la Información, Universidad de La Laguna, 2007), 263.

19 Andrew St. George, "En la Sierra Maestra. Cuatro días con Fidel Castro", El Tiempo, Bogotá, 17 de enero, 1958, 4. Traducción de Coronet, especial para periódico El Tiempo. 
Esta acción realizada en las playas de la provincia de Oriente a finales de 1956, permitiría inspirar y fortalecer psicológicamente al pueblo cubano y al Movimiento Revolucionario urbano conocido con el nombre del "Llano”, liderado por el dirigente estudiantil y después mártir de la Revolución Frank País ${ }^{20}$. Además de este grupo, los estudiantes universitarios encabezados por la Federación Estudiantil Universitaria y otros núcleos juveniles nutrirían también las filas de la oposición al régimen de Batista ${ }^{21}$.

Estos hechos y circunstancias vividas en aquel momento por el pueblo cubano, solo serían conocidos plenamente por la opinión pública internacional a partir de la primera entrevista concedida por el líder revolucionario Fidel Castro a un medio de comunicación extranjero, la cual fue realizada por Hebert Matthews ${ }^{22}$, periodista del New York Times, y coordinada por Faustino Pérez ${ }^{23}$, quien proporcionó el acompañamiento y los medios para que el periodista pudiera llegar hasta el comando central ubicado en la Sierra Maestra. Este magnífico reportaje fue acompañado de fotos de los revolucionarios que sería clave en la construcción de una primera opinión respecto al conflicto y que estaría en contravía a las declaraciones de Fulgencio Batista que persistía en asegurar la muerte de Fidel Castro ${ }^{24}$. A partir de ese momento, la idea de la revolución se propagó por todos

20 Líder revolucionario y principal dirigente de la fuerza denominada el Llano, fue capturado el 30 de julio de 1956, cuando se encontraba en casa de otro revolucionario, Raúl Pujols. Trasladados en un jeep policial fueron posteriormente maltratados y muertos en la misma calle para así evitar los requisitos legales de presentación ante las autoridades judiciales. El cuerpo del heroico revolucionario fue reclamado por su madre y vestido con uniforme verde oliva (color representativo del nuevo Ejército Revolucionario), y cubierto con la bandera cubana; su féretro fue paseado por algunas calles de Santiago. Véase: Miguel Leal Cruz, Cuba en la prensa canaria 1934-1962, 416.

21 Emilio Rodríguez Maza, "Castro, la Revolución Cubana y la autodeterminación de los pueblos", Revista de Estudios Políticos. No 124 (1962): 175-190.

22 Matthews es especialmente conocido por haber publicado en el New York Times, el 17 de febrero de 1957, una entrevista realizada al líder guerrillero Fidel Castro y difundir su lucha contra la dictadura de Fulgencio Batista. La entrevista comenzaba así: Fidel Castro, el líder rebelde de la juventud cubana, está vivo y peleando con éxito en la intrincada Sierra Maestra, en el extremo sur de la Isla. El gobierno cubano declaró públicamente que la entrevista era falsa y que Fidel Castro se encontraba muerto. El New York Times respondió publicando una foto de Matthews con Fidel Castro en su campamento de Sierra Maestra.

18023 Fue un revolucionario, político y médico cubano, integrante del Movimiento 26 de Julio, que actuó en la Revolución Cubana de 1959 y desempeñó diversos cargos en el Gobierno, destacándose el de presidente del Instituto Nacional de Recursos Hidráulicos.

24 Miguel Leal Cruz, Cuba en la prensa canaria 1934-1962, 265. 
los países de América Latina donde fue acogida con gran entusiasmo por muchos sectores sociales.

\section{Tambalea fulgencio batista}

A finales de 1957 y principios de 1958, se incrementan en Cuba las confrontaciones armadas y la lucha revolucionaria en contra de la dictadura. El ejército rebelde se fortalecía en la Sierra Maestra con la ayuda de los campesinos, y en las ciudades con el "Llano" logrando cada vez más ampliar su territorio y tener un dominio total de varias posiciones estratégicas. Este contexto es descrito en el periódico El País:

La Habana, enero 25 (UP). Grupo de rebeldes armados, compuestos de seis a ocho hombres cada uno, se abrieron paso a punta de pistola en tres estaciones de radio, por lo menos, esta tarde, y radiodifundieron una grabación preparada de antemano en que pedían al pueblo de Cuba que se levantara para derrocar "la tiranía de Batista". Las estaciones invadidas fueron la de Radio Unión, Cadena Nacional Cubana y Radio 1060. La policía inmediatamente puso patrullas en la entrada de las treinta estaciones de radio de La Habana. Los asaltos se efectuaron casi simultáneamente a las 3:30 de la tarde. Los asaltantes, que dijeron ser miembros del "Movimiento 26 de Julio" obligaron a los locutores de las estaciones a tocar la grabación que ellos les entregaron. La grabación comenzaba con el "Himno Invasor" que cantaban los patriotas cubanos en la lucha por la independencia contra España. Al terminar la música, los asaltantes obligaron al locutor a gritar “"Viva Cuba Libre”! ante el micrófono"25.

Estas incursiones eran hechas con regularidad, y buscaban instigar al pueblo a la lucha revolucionaria, evidenciando la capacidad de intervención y poder de fuerza que había logrado desarrollar el ejército rebelde en la ciudad. Mientras esto acontecía en el "Llano", en la Sierra Maestra las condiciones también eran favorables, ya que se había creado una infraestructura 
de campaña suficiente para suplir las necesidades de los pequeños pero efectivos grupos de combatientes, conformado por "una herrería, una armería, una panadería, escuelas y hospitales, donde no solo se atendían las necesidades propias, sino también a los campesinos de toda la región circundante" 26 . Logros obtenidos a través de los continuos combates contra las fuerzas gubernamentales, donde se conseguían suministros necesarios para continuar con la lucha y sostener a los combatientes que cada día se iban sumando a la causa. Estos hechos fueron acompañados por el periódico El Tiempo con la siguiente nota:

"Nueva York, enero 15 (UP). Círculos del movimiento del 26 de julio aquí dijeron que las fuerzas rebeldes de Fidel Castro activas desde hace más de un año en la región oriental de Cuba, tuvieron dominado el lunes durante varias horas en el triángulo formado por Manzanillo, Campeche y Yara. Las fuerzas de gobierno no presentaron resistencia en ninguno de los puntos. Considerándose, esta la acción más audaz realizada por los rebeldes cubanos... La operación rebelde tuvo los siguientes resultados: Castro obtuvo armas, pertrechos y alimentos que necesitaba urgentemente... Subrayó que la actitud pasiva de las fuerzas del Gobierno denotaba desmoralización entre ellas"27.

Estos avances conquistados por los rebeldes de Castro, tendrían eco en la prensa internacional y latinoamericana que continuamente posaba sus ojos sobre el desarrollo del conflicto, fue así que para el año de 1958 se puede encontrar un sinnúmero de noticias en El País y El Tiempo. Además de estas comienzan a aparecer las primeras fotografías y caricaturas donde son registrados y representados los eventos que están aconteciendo en Cuba y también otros que tenían una estrecha relación con la tiranía y los regímenes dictatoriales que estaban pasando por su peor momento en algunos países del continente, como el caso de Venezuela y Colombia, que habían visto caer en los dos últimos años los regímenes políticos de Marcos Pérez Jiménez (1953-1958) y del general Rojas Pinilla (1953-1957).

26 Miguel Leal Cruz, Cuba en la prensa canaria 1934-1962, 274.

27 Editorial, "Audaz asalto de las fuerzas de Fidel Castro en Manzanillo. Durante cuatro horas dominaron extensa región. Importante botín logran los rebeldes", El Tiempo, Bogotá, 14 de enero de 1958, 7. 
La primera (Imagen 1) titulada "Temblando en Cuba" muestra al presidente Fulgencio Batista un poco nervioso por el temblor de tierra que estaba sintiendo y le pregunta a "Liborito"28: “¿Dónde estará el epicentro de este temblor?" y este responde: "Parece que primero estaba en Bogotá y ahora en Caracas", haciendo alusión a los eventos ocurridos en estas capitales de Colombia y Venezuela que vieron cómo se desmoronaban los regímenes dictatoriales que se habían instaurado en estos dos países.

La segunda (Imagen 2) sería la confirmación de ese hecho. En la caricatura, se muestra en la parte alta a los dos generales, Batista y Trujillo, que se encuentran muy angustiados mientras ven caer a sus homólogos Rojas y Pérez Jiménez hacia un precipicio, acompañados de una frase que dice "al primero sigue más y los otros van detrás”. En la imagen, también aparece una mano que sale de una esquina del recuadro y un sombrero conocido con el nombre de kepis militar, utilizado por oficiales de alto rango como generales. Es probable, que este sea el sombrero y la mano del militar Juan Domingo Perón de Argentina que había sido derrocado a través de un golpe ocurrido el 16 de septiembre de 1955.

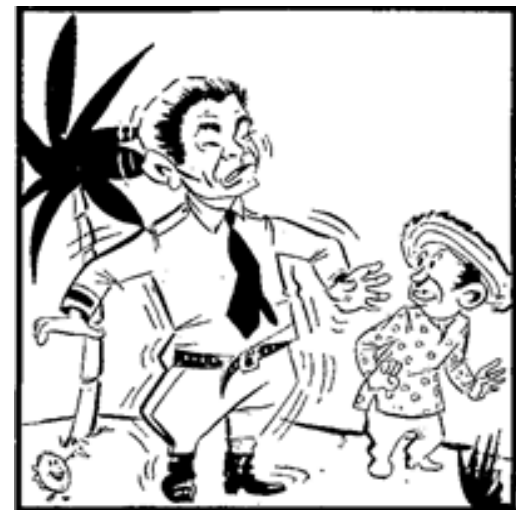

Imagen 1

Título: Temblando en Cuba

Fulgencio: ¿Dónde estará el epicentro de este temblor?

Liborito: Parece que primero estaba en Bogotá y ahora en Caracas

Fuente: Diario El Tiempo, 13 de enero de 1958. Por Chapete.

28 Así como el "Tío Sam” simboliza al pueblo norteamericano, Liborio es el personaje que simboliza al pueblo de Cuba. Liborio representa al legítimo campesino cubano, ataviado con sombrero de yarey, guayabera blanca de hilo, pañuelo rojo al cuello y machete al cinto. Ver: Hernández Fonseca, e-mail al Comandante. Caricaturas de PONG (Brasil: Editora Belém do Pará, 2006). 


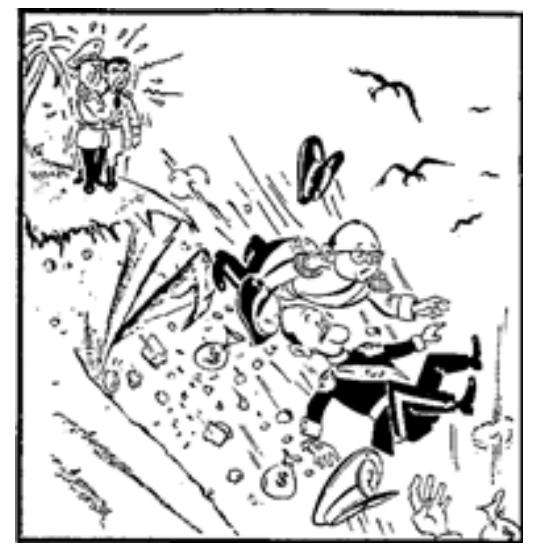

Imagen 2

Título: Se cayó... Se cayó... Se Cayó!

"Al primero siguen más y los otros van detrás"

Fuente: Diario El Tiempo, 24 de enero de 1958. Por Chapete.

En el mismo mes en que son publicadas estas dos caricaturas en El Tiempo, el periódico El País publica una imagen que representa al dictador Fulgencio Batista tambaleando encima de una isla (Imagen 3), mientras un minúsculo insecto lo indispone y desequilibra. Un mensaje contundente y directo, que muestra la inestabilidad por la que estaba pasando el régimen cubano. La construcción visual de la caricatura es muy diciente, los rasgos del personaje son claramente identificables, rostro, vestuario y espacio permite establecer una relación directa con Batista en Cuba.

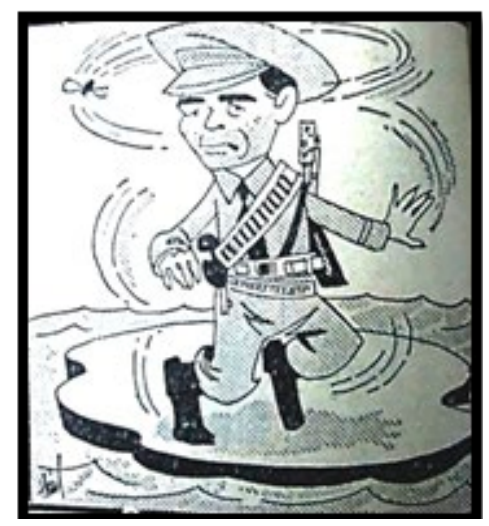

Imagen 3

Título: ¿Qué será... será...? ¿...Será un bolero .... "una bolera"...?

Fuente: Periódico El País. Cali 30 de enero de 1958. Por Hernández. 
A la composición gráfica se le suma un elemento más, un pequeño insecto que rodea al mandatario perturbándolo de forma desesperante, un personaje que podíamos relacionar con los rebeldes, o por qué no, con el mismo Fidel Castro que para aquel momento, se habían convertido en una amenaza y que fueron subestimados en un principio por las fuerzas gubernamentales, llegándolos a considerar como una pequeña incomodidad, pero nunca como un verdadero riesgo para el Gobierno.

Estas imágenes pueden ser entendidas en las palabras de Luis de Zulueta, escritor y político español que colaboró para varios periódicos de renombre como El Liberal, El Sol y La Libertad. En un artículo publicado por el periódico El Tiempo llamado "Cambió el clima moral del mundo. La caída de las dictaduras", Zulueta discute sobre los últimos acontecimientos que han tenido lugar en la agitada política latinoamericana en 1958, donde poco a poco los tiranos y dictadores fueron divisando su ocaso como lo hizo Batista en Cuba y después Trujillo en República Dominicana:

“...En la América Latina, cayó Perón, cayó Rojas Pinilla, cayó Pérez Jiménez. Caerá mañana... Los ojos se vuelven hacia el mar de las Antillas. Dictaduras que recurran a los métodos crueles que han levantado en masa al pueblo de Caracas, se hundirá indefendiblemente..."29.

Para el mes de febrero de 1958, en las noticias publicadas por el diario El País, ya estaban profetizando una posible derrota del régimen. Su encabezado decía: "Batista empieza a temblar; lucha a muerte en Oriente. Los rebeldes y el Ejército en gran batalla" 30 . Este titular venía acompañado de un pequeño texto, el cual relataba que se estaba llevando a cabo una gran batalla entre los rebeldes y el ejército cerca de Campechuela. Esta última era una pequeña localidad situada a los pies de la Sierra Maestra y las infor-

29 Luis de Zulueta, "Cambió el clima moral del mundo. La caída de las dictaduras", El Tiempo, Bogotá, 1 de febrero de 1958.

30 United Press International, "Batista empieza a temblar; lucha a muerte en Oriente. Los rebeldes y el ejército en gran batalla", El País, Cali, 12 de febrero de 1958, 8. 
maciones procedían de Manzanillo, una población próxima en donde se escuchaba claramente el fragor de la batalla. Para estas alturas del conflicto, el grupo rebelde había interiorizado muy bien el combate de guerrillas y era cada vez más difícil para las fuerzas regulares tener éxito concreto durante los combates.

Estas noticias eran acompañadas por la mirada crítica de los intelectuales de la sátira política que estaban prediciendo la posible caída que se avecinaba para el dictador Fulgencio Batista. Algunas de estas representaciones mostraban a este mandatario en compañía de su homólogo Rafael Trujillo, donde eran dibujados como hijos de una tiranía (Imagen 5) que se había instaurado en las Antillas.

En la representación gráfica de las siguientes caricaturas, se pueden encontrar dos tipos de alegorías. Por un lado, está una simple que emplea un lenguaje común y entendible para todo tipo de público, donde la expresión "porrazo seguro" (Imagen 4) permite entender una caída y golpe del gobierno de Batista, mientras que la otra es un poco más compleja puesto que es necesario tener un conocimiento básico de historia para establecer una asociación simbólica entre su contenido y significado.

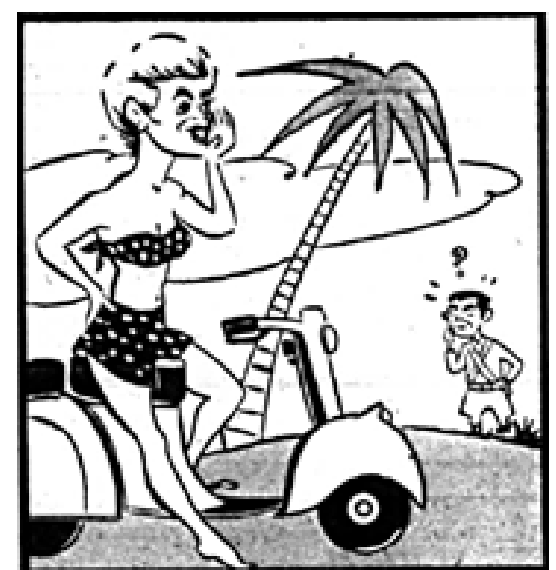

Imagen 4

Título: Porrazo seguro

Fulgencio... quieres aprender a montar en motoneta...

Fuente: Diario El Tiempo, 2 de febrero de 1958. Por Chapete 


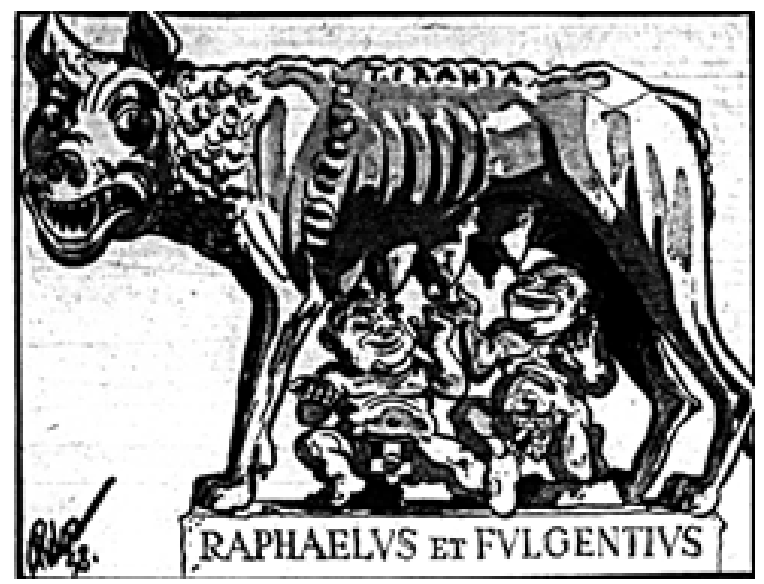

Imagen 5

Título: Todavía quedan

...Los Fundadores...

Fuente: Diario El Tiempo, 13 de febrero de 1958. Por Aldor

En esta última caricatura (Imagen 5), Peter Aldor utiliza la simbología que encierra la estatua de bronce de la loba capitolina o Luperca que se encuentra en los Museos Capitolinos en Roma, para representar a los hijos gemelos Raphaelvs (Rafael Trujillo) y Fvlgentivs (Fulgencio Batista) que están siendo amamantados por la tiranía, así como Rómulo y Remo fueron amantados por Luperca, lo cual dio origen a la leyenda fundacional del Imperio Romano.

Entrando el mes de marzo de 1958, las caricaturas publicadas en los periódicos El País y El Tiempo evidencian claramente a lo que se estaba enfrentando el dictador. La primera es la representación de una posible democracia para Cuba que es personificada por una bola de béisbol (Imagen 6), que se acerca rápidamente mientras el inestable y temeroso general la espera. ¿Será que le llegó la hora al "Batista”?, ¿será que logrará dar un jonrón o saldrá ponchado en primera base? Tal vez, el arribo de esa democracia se deba a que "Don Fulgencio" no aprendió nada de sus amiguitos (Perón de Argentina y Pérez de Venezuela), que en un momento dado se cayeron del triciclo llamado dictadura y que está siendo imposible de controlar (Imagen 7). Dos caricaturas, que estaban reforzando un imaginario de decadencia sobre los últimos momentos del régimen dictatorial: 


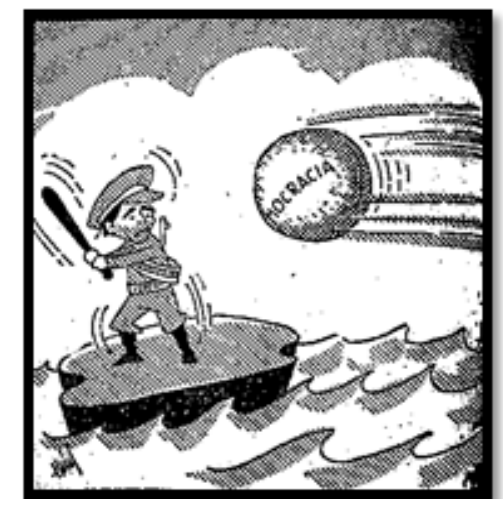

Imagen 6

Título: De bola a bola

Ahora le toca al "Batista"

Fuente: Periódico El País. Cali 21 de marzo de 1958. Por Hernández.

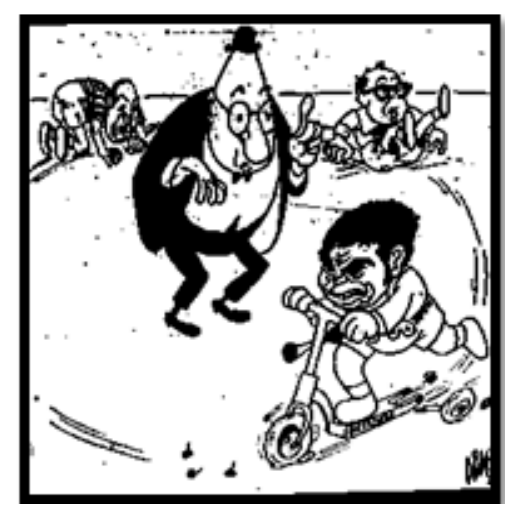

Imagen 7

Título: Don Fulgencio

Don Fulgencio: Parece que no aprendiste nada de tus amiguitos Fuente: Diario El Tiempo, 11 de marzo de 1958. Por Aldor.

Este imaginario era complementado por algunas noticias publicadas al inicio del año por El Tiempo, que describían las intenciones de los rebeldes dirigidos por Castro en la Sierra Maestra y que significaba el retorno de la democracia y las garantías constitucionales para el pueblo cubano:

"Nos hemos propuesto a derrocar a Fulgencio Batista y a todos sus altos agentes inmediatos, arrestarlos y hacerlos comparecer ante tribunales revolucionarios especiales. Para sustituir el régimen de Batista, contribuiremos a la instauración de un gobierno provisional, que será designado por una convención especial, in- 
tegrada por delegados de diversas organizaciones cívicas... preparación y dirección de comicios generales honestos que habrán de efectuarse en plazo de doce meses..." 31 .

A partir de ese instante, el gobierno de Batista tuvo una dificultad enorme para recuperarse y en los últimos meses de 1958 los enfrentamientos se hicieron cada vez más fuertes, y Cuba sería testigo del ocaso de un régimen que ya había sacado el suficiente usufructo de su pueblo. El anhelo de crear mejores condiciones sociales, se divisaba en el horizonte y se fortalecía con cada incursión que realizaba el ejército rebelde.

Debido a los últimos acontecimientos, la credibilidad del general Batista para dirigir el país era puesta en duda y su imagen había decaído mucho. Este era representado en las caricaturas, como un dictador sediento de poder y de sangre (Imagen 9). Por otra parte, Castro era mostrado como el vencedor en todos los aspectos y el encargado de expulsar a este dictador de la isla como lo muestra "El nuevo escudo de Cuba" (Imagen 8):

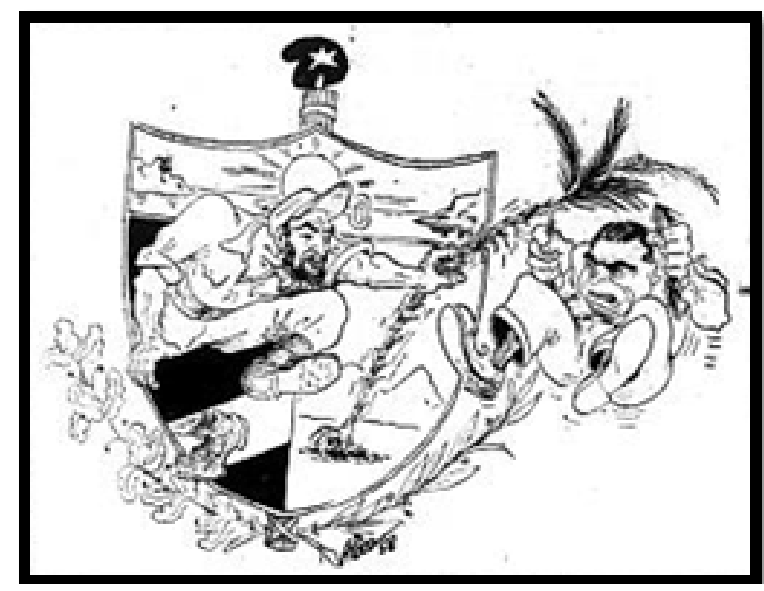

Imagen 8

Título: El Escudo de Cuba

Fuente: Diario El Tiempo, 16 de marzo de 1958.

31 Editorial, "Habla Fidel Castro. La libertad, el objetivo de nuestra lucha. Un escrito especial del jefe de la rebelión cubana", El Tiempo, Bogotá, 16 de enero de 1958, 5 (Una traducción especial de "Coronet", para El Tiempo). 


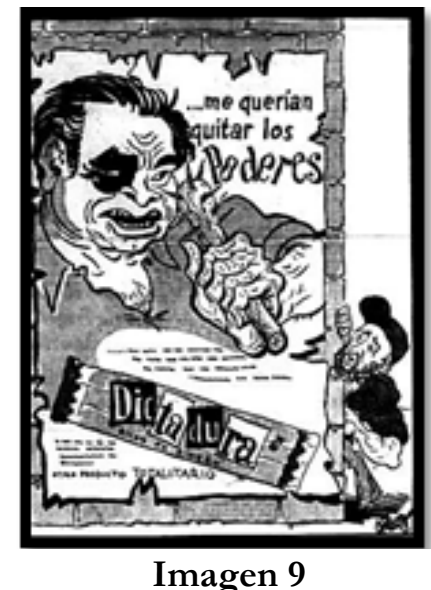

Título: Carteles en Cuba

Fuente: Diario El Tiempo, 24 de abril de 1958. Por Aldor

En medio de su derrota, Fulgencio Batista huye de la isla el 1 de enero de 1959, pasadas las 2:30 de la madrugada en un avión con destino a República Dominicana. En el avión, lo acompañaba su esposa y algunos allegados. Antes de partir, Batista relevó de sus mandos a los jefes militares y nombró al general Eulogio Cantillo Porras como jefe supremo de todas las fuerzas de tierra, mar y aire ${ }^{32}$.

\section{Triunfó la REVOLUCióN}

La noticia de que el dictador había huido de Cuba, no dio espera y corrió como pólvora encendida. Después de dos largos años de combate, por fin, la lucha revolucionaria se encontraba a las puertas del triunfo. Muy pronto llegó a oídos de la población, la cual se llenó de alegría y júbilo. Las calles y las plazas de las principales ciudades comenzaron a llenarse de personas que gritaban la victoria de la revolución. Luis M. Buch Rodríguez, un testigo presencial de los hechos describe el momento:

"Para mí fue un momento excepcional. Pude observar a las personas que se abrazaban, saltaban y corrían. Unos lloraban de feli-

32 Luis Buch Rodríguez y Reinaldo Suárez, Gobierno Revolucionario Cubano. Primeros pasos (La Habana: Editorial de Ciencias Sociales, 2009), 34. 
cidad; otros, lo hacían por sus muertos, mártires de la Revolución. Fueron instantes de grandes y profundas meditaciones, mientras observábamos aquellas escenas indescriptibles y conmovedoras del pueblo, que al fin estaba libre del yugo de la tiranía más cruenta que recuerda nuestra historia republicana"33.

Pero antes de declarar una victoria oficial, Fidel Castro actuó con cautela, ya que en la capital un grupo de militares al mando de Cantillo estaba fraguando un golpe. Rápidamente, el líder guerrillero realiza un pronunciamiento a través de "Radio Rebelde", impartiendo instrucciones a los santiagueros y a los jefes rebeldes de los diferentes frentes que estaban en posición de avance:

"Batey del central "América". Cualesquiera que sean las noticias procedentes de la capital, nuestras tropas no deben hacer alto al fuego en ningún momento. Nuestras fuerzas deben proseguir sus operaciones contra el enemigo en todos los frentes de bata1la. Acéptese solo conceder parlamento a las guarniciones que deseen rendirse. Al parecer, se ha producido un golpe de Estado en la capital. Las condiciones en que ese golpe se produjo son ignoradas por el ejército rebelde. El pueblo debe estar muy alerta y atender solo las instrucciones de la comandancia general. La dictadura se ha derrumbado como consecuencia de las aplastantes derrotas sufridas en las últimas semanas, pero eso no quiere decir que sea ya el triunfo de la revolución..."34.

Tras la caída del régimen corrupto, la desintegración de las fuerzas armadas, la huida del dictador y la contención de un golpe militar liderado por Cantillo, por fin, vence la revolución el 1 de enero de 1959. Este triunfo daría paso al surgimiento de un Estado revolucionario donde la dignidad del pueblo sería su principal motivo de lucha ${ }^{35}$.

33 Luis Buch Rodríguez y Reinaldo Suárez, Gobierno Revolucionario Cubano. Primeros pasos, 36.

34 Fidel Castro Ruz, La victoria estratégica. Por todos los caminos de la Sierra. La contraofensiva estratégica. De la Sierra Maestra a Santiago de Cuba. (Madrid: Ediciones Akal, S.A., 2012), 583.

35 Leslie Bethell, Historia de América Latina. México y el Caribe desde 1930 (Barcelona: Crítica, 1998). 
Las primeras manifestaciones públicas en el diario El País, pretendían crear un estado de incertidumbre en la opinión pública respecto al nuevo gobierno revolucionario. Informaciones procedentes de Nueva York desarrollaban una noticia que decía: "Batista, como Castro luchó contra un tirano" 36 . Encabezado que había sido copiado del periódico Wall Street Journal, donde su editorial dejaba clara la idea de que Batista también había combatido contra una opresión y que una vez alcanzada una elevada posición, se había olvidado completamente de su propósito al ser seducido por el poder. Finalmente cierra diciendo: "Quizás Fidel Castro aprovechará la experiencia de su predecesor. Batista no aprendió la lección que él mismo enseñó"37.

Por su parte, el periódico El Tiempo en los primeros días de enero realiza un despliegue informativo donde muestra los diferentes acontecimientos que se estaban viviendo en Cuba. En las noticias se puede evidenciar una imparcialidad sobre el nuevo gobierno revolucionario que se perfila y el transitorio dejado por Batista tras su huida a República Dominicana. En algunos titulares se reivindican el heroísmo y la tenacidad de la fuerza revolucionaria del Movimiento 26 de Julio liderado por Fidel Castro y de sus tropas victoriosas ${ }^{38}$.

A esta imagen, se suman una serie de caricaturas que muestran al general Fulgencio Batista llegando al club de los exdictadores (Imagen 10) que se encontraba operando en República Dominicana, destino preferido por algunos que fueron depuestos de su gobierno. Por otra parte, Castro es mostrado como el vencedor de una contienda donde Batista ha dejado la lona tras su derrota (Imagen 11), mientras que un nuevo rival de la democracia aparece en escena para desestabilizar el triunfo que conquistó el ejército revolucionario en Cuba:

36 United Press International, "Batista, como Castro luchó contra un tirano", El País, Cali, 5 de enero de 1958, 14.

37 United Press International, "Batista, como Castro luchó contra un tirano", El País, 14.

38 Editorial, "Fidel Castro y Urrutia llegan hoy a La Habana. Las tropas victoriosas entran a la capital", El Tiempo, Bogotá, 3 de enero de 1959, 1. 


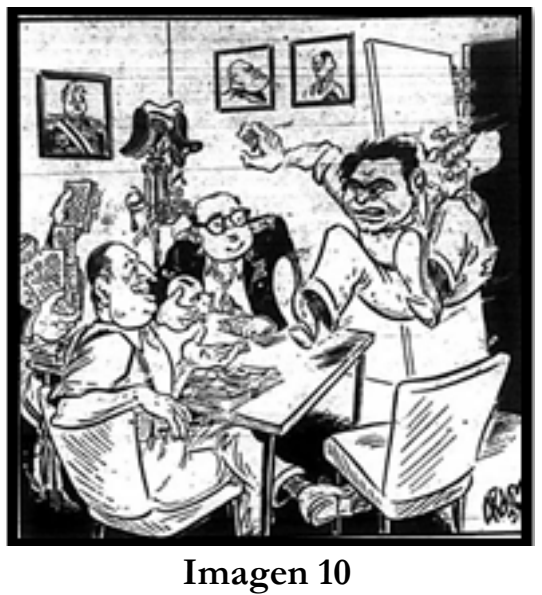

Título: El club de los exdictadores

Perón: -Ché, Marco: armemos el "bridge" que este también trae plata...

Fuente: Diario El Tiempo, 3 de enero de 1959. Por Aldor.

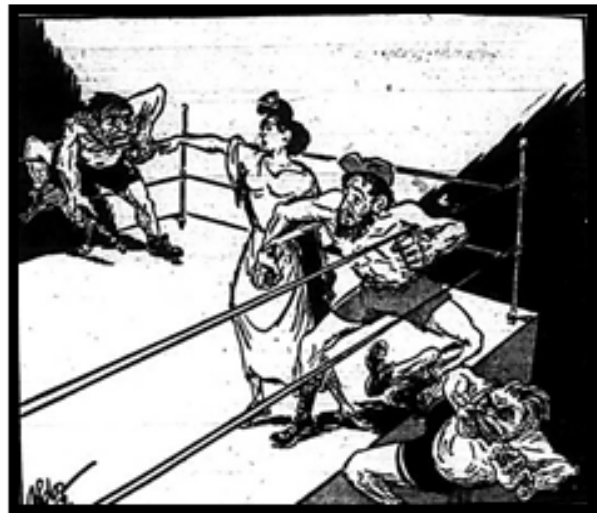

Imagen 11

Título: Lucha libre

La democracia: Para que completemos el triunfo, ¿por qué no acabamos también con el homicidio?

Fuente: Diario El Tiempo, 14 de enero de 1959. Por Aldor

Este personaje va a ser el responsable de abrir una brecha entre la opinión pública internacional y algunos sectores políticos que sintieron la victoria del Movimiento 26 de Julio como el mayor logro conseguido en contra de la tiranía en el continente americano. La violencia sería entonces la protagonista de esta caricatura que sería representada como la próxima dificultad que Fidel Castro tendría que asumir días después de su triunfo. Esta se expresaba en los diferentes fusilamientos y juicios revolucionarios que emprenderían en contra de aquellos colaboradores del saliente gobierno. 
El 8 de enero de 1959 llega triunfal a La Habana Fidel Castro Ruz, el líder rebelde de 32 años que había expulsado del poder al dictador Fulgencio. Entre salvas de artillería, repiques de campanas y las ovaciones populares de cientos de miles de personas es recibido. Los establecimientos comerciales, las industrias y las oficinas cerraron en toda la ciudad a las once de la mañana para permitir a sus empleados tomar parte en la recepción de Castro. Las baterías de la fortaleza de la Cabaña, que domina la entrada del puerto de La Habana saludaron al líder con 21 cañonazos a las 12:55 de la tarde, mientras las campanas de las iglesias en toda la ciudad sonaban al ritmo de triunfo ${ }^{39}$.

A estas alturas, la noticia de la Revolución Cubana se había esparcido por todo el mundo, especialmente en Latinoamérica y la onda revolucionaria contagiaba a sus adeptos. Esto también fue mostrado en imágenes y caricaturas, donde el espíritu combativo era representado con lo más sobresaliente del ejército rebelde: el fusil, un uniforme verde oliva y una barba prolongada, que se convertiría en el símbolo del revolucionario (Imagen 12).

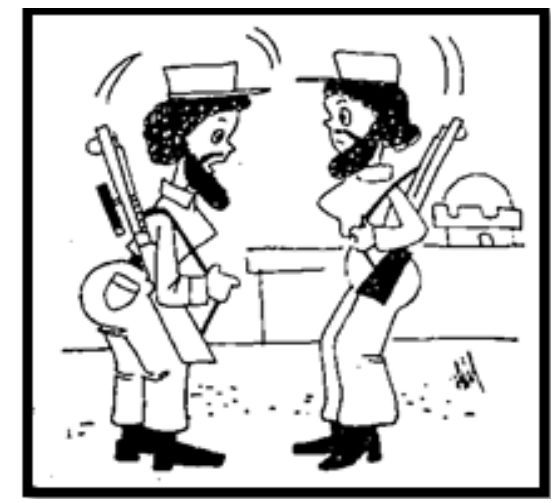

Imagen 12

Título: Revolucionarias

Ah! A ti también...

Fuente: Diario El País, 19 de febrero de 1959. Por Hernández

39 United Press International, "Fidel Castro entró a La Habana en medio del delirio colectivo de su pueblo”, El País, Cali, 8 de enero de 1959, 12. 


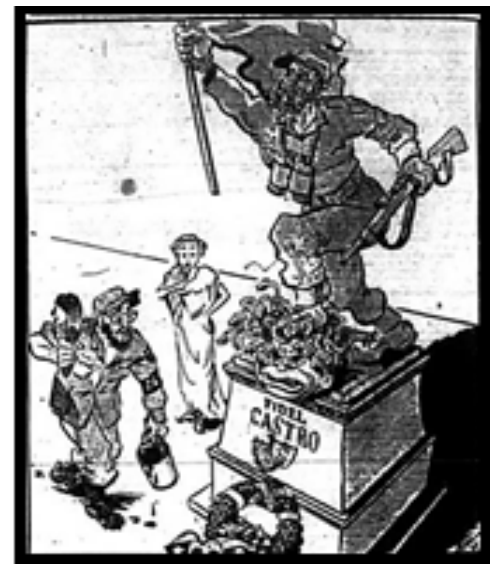

Imagen 13

Título: En Cuba

La democracia: Sería lástima que mancharas tu propia estatua

Fuente: Diario El Tiempo, 11 de marzo de 1959. Por Aldor

La figura de Fidel Castro también era utilizada para reivindicar el espíritu revolucionario; este era representado como el héroe que cortó la cabeza de la monstruosa tiranía para conquistar la libertad de su pueblo y enaltecer su bandera (Imagen 13). Una imagen de aceptación que con el paso del tiempo iría a cambiar por las diferentes medidas adoptadas en la primera etapa de la Revolución Cubana y que mancharía el imaginario que hasta el momento se había construido.

Según José Ruiz Hernández, el año de 1959 será reconocido como la etapa democrática, popular, agraria y antiimperialista. Esta se caracterizaría por una serie de medidas que obedecían a las necesidades del pueblo cubano. La primera de ellas consistía en la destrucción del aparato estatal burgués, donde el viejo ejército y la policía fueron desarmados y disueltos quedando en su lugar el ejército rebelde. Otra medida sería garantizar la soberanía nacional y las conquistas revolucionarias a través de la depuración del aparato judicial. Simultáneamente a estas medidas, se crean los tribunales revolucionarios para juzgar y sancionar a los torturadores, delatores y criminales del régimen saliente ${ }^{40}$.

40 José Ruiz Hernández, Cuba, Revolución social y salud pública 1959-1984 (La Habana: Editorial Ciencias Médicas, 2008), 24. 


\section{El PAREDÓN DE LOS DERROTADOS}

El primer mes de la revolución castrista pasó de ser un hecho glorioso de exaltación, a ser un acontecimiento cuestionado por la opinión pública internacional. Esta situación obedecía a la forma de proceder del ejército rebelde en relación a los partidarios de Batista, que según estos, estaban siendo asesinados por los revolucionarios sin que se celebraran juicios legítimos y con garantías.

Para los revolucionarios solo se trataba de un ajuste de cuentas con la estructura dictatorial del régimen saliente que durante muchos años había torturado y asesinado a los opositores políticos. Para llevar a cabo esto, se crearon tribunales donde eran juzgados y después fusilados rápidamente los encontrados culpables. Aunque muchos otros pensaban que estos juicios solo eran "representaciones teatrales, utilizadas para divertir a las personas que veían cómo condenaban al paredón a un pobre diablo" ${ }^{41}$, en el cual morían inocentes y culpables, creando un espectáculo que era muchas veces transmitido por la televisión.

La caricatura entra a jugar un papel importante en este episodio, ya que era un tema que molestaba a la opinión pública internacional y cuestionaba las verdaderas intenciones de libertad que proponía el actual gobierno de Cuba. Una de ellas publicada el 26 de agosto de 1959, muestra a Fidel Castro y su hermano Raúl Castro con una marioneta de Osvaldo Dorticos Torrado (julio 1959-1976), quien asumió la presidencia de Cuba tras la salida de Manuel Urrutia (Imagen 14). En ella el temido y ahora sin cabeza Maximilien Robespierre, advierte a Fidel sobre las consecuencias de sus acciones y en especial sobre la idea de eliminar a todos los opositores. La caricatura deja claro a quién pertenecía el verdadero poder político de Cuba, y que las demás figuras del gobierno como Osvaldo Dorticos solo eran títeres que podían ser dirigidos a su conveniencia y voluntad:

41 Raquel Egea Casas, "Revolución Cubana: la represión castrista vista a través de la persecución y encierro de Reinal Arenas en la prisión del Morro", Revista Semestral de Iniciación a la Investigación en Filología. Vol. 5, (2011): 68. 


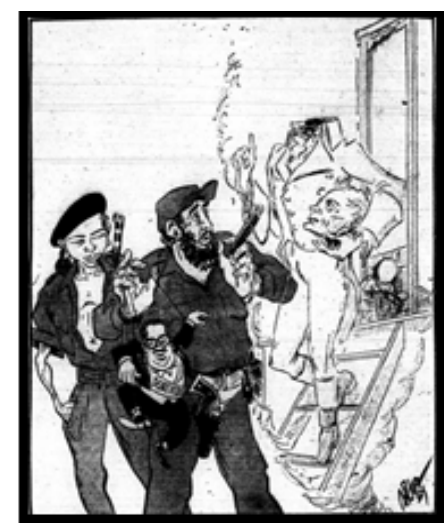

Imagen 14

Título: La advertencia de Robespierre

-Yo también quise eliminar a todos mis opositores..

Fuente: Diario El Tiempo, 26 de agosto de 1959. Por Aldor

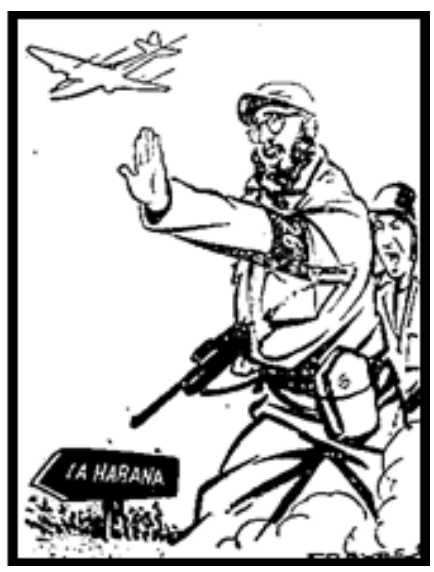

Imagen 15

Título: Baño de sangre

No dejen de matar...

Fuente: Periódico El País, Cali 8 de febrero de 1959. Por Freyre.

En otra caricatura publicada el 8 de febrero de 1959 por el periódico El País, se evidencia la necesidad de hacer un llamado a la cordura sobre el baño de sangre que se estaba viviendo en Cuba. En la imagen se puede identificar con facilidad a sus protagonistas: en un primer plano Fidel Castro con su brazalete distintivo del Movimiento 26 de Julio, seguido de su hermano Raúl Castro que exclaman: “...No dejen de matar...” (Imagen 15). El mensaje es claro y directo: no dejar de asesinar, exterminen la oposición, continúen con el baño de sangre en La Habana; un imaginario que pretendía crear El País respecto a los últimos acontecimientos que se 
estaban tejiendo en Cuba. Pasar de ser admirados, elogiados y hasta convertidos en héroes por derrotar a una de las dictaduras más sombrías por la que había pasado Cuba, a ser llamados sanguinarios y dejar en entredicho la aceptación que el pueblo latinoamericano le había proporcionado a la revolución.

En una entrevista hecha a Castro, este declara que los fusilamientos que estaban teniendo lugar en La Habana eran justificados ${ }^{42}$, lo cual negaba completamente las acusaciones que realizaban algunos medios imperialistas, de que en la isla se estuviera ejecutando sin previo proceso a los partidarios del depuesto presidente Fulgencio Batista. Finalizando la entrevista, Castro reiteró su promesa de que Cuba tendría elecciones libres en un año y medio de acuerdo con la Constitución de 1940. Cuando se preguntó respecto a las críticas que estaban haciendo algunos políticos norteamericanos, Castro expresó: “Tengo una alta opinión de los norteamericanos que conocí antes, durante y después de la rebelión pero tengo críticas que hacer al gobierno de Estados Unidos" ${ }^{43}$. Estas declaraciones retumbarían en el Senado de Estados Unidos y en la Casa Blanca en Washington, propiciando un proceso de disentimiento entre las dos naciones. No pasaría mucho tiempo para que los primeros pronunciamientos se produjeran.

El primero en hacerlo fue el senador Wayne Morse, quien afirmaba que las ejecuciones de los partidarios de Batista eran reprochadas por el mundo entero y que ello le podría crear al gobierno revolucionario una animadversión de América Latina ${ }^{44}$. Este legislador manifestaba que no veía con buenos ojos la "nueva justicia cubana" que estaba produciendo un baño de sangre. Agregando Morse, que tal acción "no es humana, ni cristiana, y no es la forma de crear buena voluntad entre los hombres y mujeres libres de todo el mundo"'45.

$42 \quad$ United Press International, "F. Castro justifica los fusilamientos. Declara que se hizo justicia con los criminales", El País, Cali, 11 de enero de 1959, 8.

43 United Press International, "F. Castro justifica los fusilamientos. Declara que se hizo justicia con los criminales", El País, 8.

19844 United Press International, "El baño de sangre en Cuba. Críticas en el Senado de Estados Unidos. Los fusilamientos causan el desprestigio de Urrutia", El País, Cali, 13 de enero de 1959, 11.

45 United Press International, "Los fusilamientos de los partidarios de Batista. El baño de sangre hará perder el prestigio a Cuba. Cárcel y no muerte pide un senador norteamericano. América deplora las ejecuciones". El País, Cali, 12 de enero de 1959. 
Este sentimiento de inconformismo sería manifestado a través de los trazos de la caricatura, donde se representaría el descontento en la imagen titulada "De castaño a oscuro" (Imagen 17) que utiliza irónicamente el seudónimo de barbudos que generalmente se empleaba para referirse a los revolucionarios cubanos y se complementa con la prolongación de la misma resaltando que todo esto era “una barba...ridad!!”. En otra imagen publicada en El Tiempo (Imagen 16), América Latina se sorprendía por esa nueva historia que estaba escribiendo con sangre Fidel Castro y que sería aprovechada por sus contradictores para desprestigiar al gobierno revolucionario:

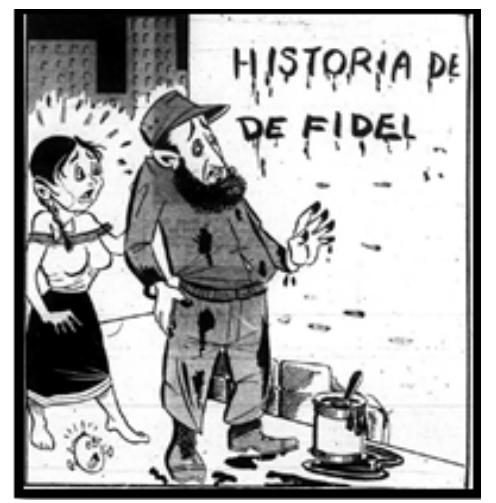

Imagen 16

Título: Escribiendo la historia

América Latina: Por Dios, Fidel, no en el PAREDÓN

Fuente: Diario El Tiempo, 30 de octubre de 1959. Por Chapete

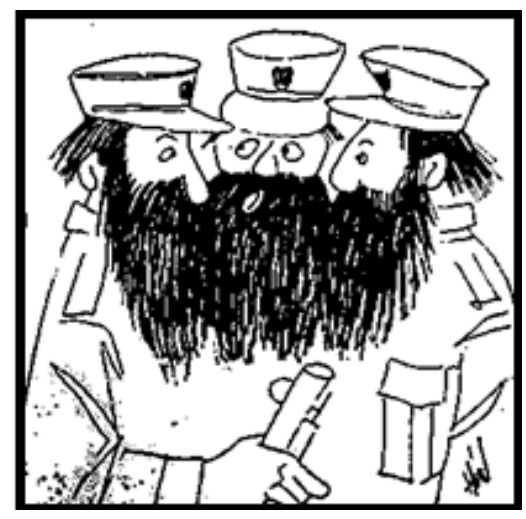

Imagen 17

Título: De castaño a oscuro

Decía yo que todo esto se me hace una barba...ridad!!

Fuente: Periódico El País, Cali 3 de abril de 1959. Por Hernández. 
De este modo se iniciará una confrontación directa a través de los medios de comunicación y las caricaturas para deslegitimar las transformaciones sociales que se estaban llevando a cabo en Cuba. Un ejemplo es la imagen titulada "Cuba Libre" donde se ponen en evidencia las continuas críticas de la opinión internacional respecto a los fusilamientos masivos (Imagen 18). Situación que colocaría en duda (Imagen 19), la verdadera posición que debería tomar Estados Unidos respecto a la isla en el Caribe:

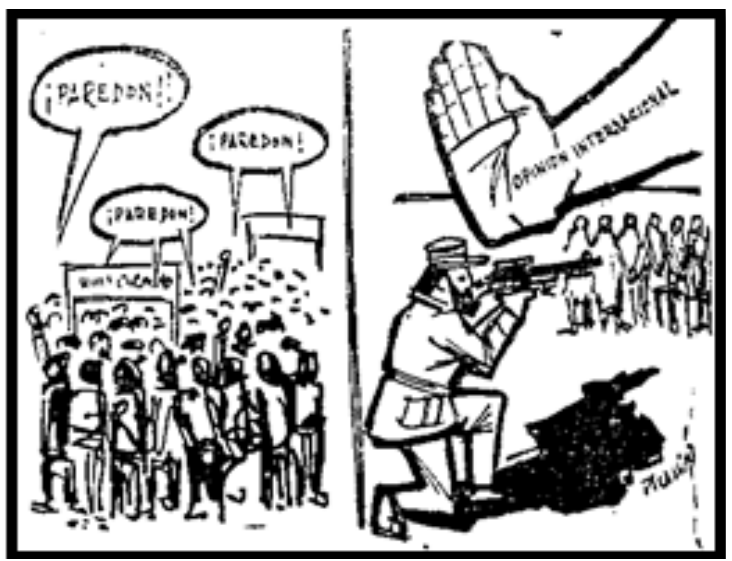

\section{Imagen 18}

Título: Cuba Libre

“PPAREDÓN!”

Fuente: Periódico El País, Cali 1 de noviembre de 1959. Por Picassini.

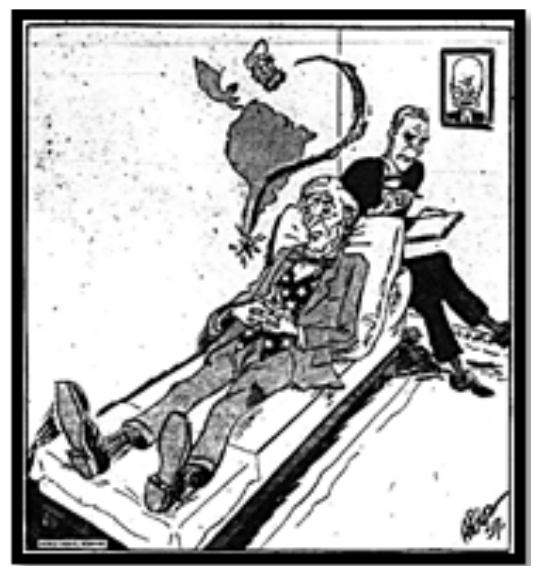

Imagen 19

Título: Castrofobia

Fuente: Diario El Tiempo, 29 de noviembre de 1959. Por Aldor 
La Imagen 18 se compone de dos escenas: en la primera aparece una turma un grupo de personas gritando "Paredón", mientras que en la segunda, se reconoce la figura de Fidel Castro, quien se encuentra apuntando hacia un paredón de fusilamiento, a su vez una mano grande y firme se presenta en señal de "alto", en ella una inscripción: “opinión internacional". La Imagen 19 muestra al Tío Sam que se encuentra en una consulta con el Secretario de Estados Unidos, Christian Herter, para despejar sus dudas sobre Cuba, las cuales han sido provocadas por una "Castrofobia" que no consigue superar hasta el momento.

Las críticas de los Estados Unidos y de la opinión internacional crearían un escenario tenso de desconfianza y recelo sobre los acontecimientos que estaban teniendo lugar en Cuba y Washington veía el problema cubano como una bomba de tiempo (Imagen 20) lista para ser encendida por su mayor contendor (URSS), donde Cuba cada vez más inclinaba su proyecto político hacia el comunismo y la figura heroica de Fidel Castro se transformaría en una leve silueta que se desvanecería en el ocaso de 1959 (Imagen 21):

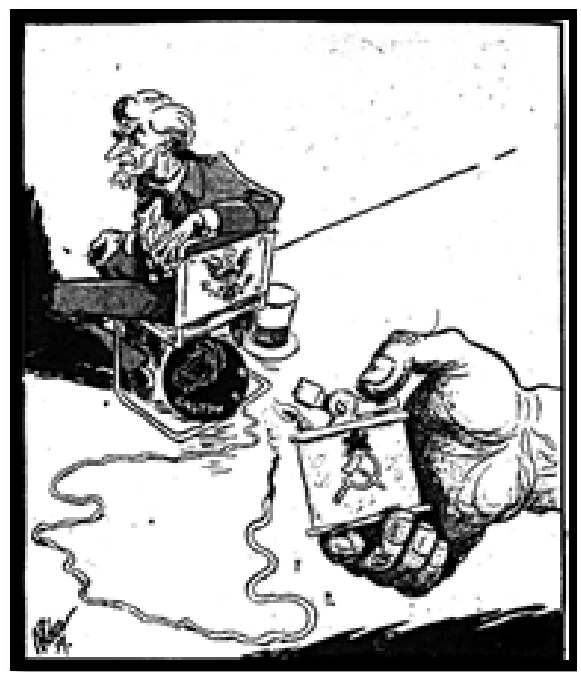

Imagen 20

Título: El problema cubano

...Visto desde Washington...

Fuente: Diario El Tiempo, 15 de noviembre de 1959. Por Aldor. 


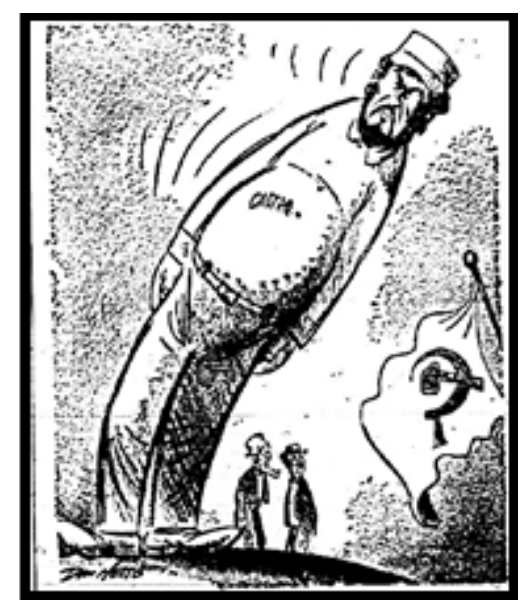

Imagen 21

Título: Inclinaciones

Tan inclinado a la izquierda que puede caerse

Fuente: Diario El Tiempo, 31 de agosto de 1960. Por Don Esse

\section{Consideraciones finales}

A lo largo de este artículo se han podido reunir una serie de argumentos que permiten asegurar que la caricatura política encontrada en los periódicos El País y El Tiempo se constituyó en un instrumento simbólico utilizado por la prensa escrita para la representación de los acontecimientos desarrollados en Cuba entre 1958 y 1959. Constituida a partir de signos, metáforas, símbolos y figuras de personajes reconocidos que se entrelazaban con titulares, columnas de opinión y discursos políticos promovidos por estos periódicos. En ella se puede identificar claramente un interés político e ideológico de características geopolíticas que sobrepasaba las fronteras a través de la construcción de dos tipos de discursos.

En el primero, la revolución fue mostrada como la respuesta a los problemas del pueblo cubano que se encontraba bajo el régimen corrupto de Fulgencio Batista. Este discurso fue percibido en aquellas noticias y caricaturas que se publicaron antes del 1 de enero de 1959 y durante el primer trimestre de ese mismo año, cuando aún no se habían producido mayores trastornos en los intereses norteamericanos.

El segundo discurso es un poco más radical porque su principal objetivo 
consistía en desmitificar la conquista de la Revolución Cubana como un logro de la democracia y la lucha de las clases sociales latinoamericanas mostrando al gobierno revolucionario como el transgresor de las libertades y los derechos humanos al proceder de la misma forma que su antecesor cuando fue ejecutada la oposición mediante los fusilamientos masivos de los batistianos.

Este discurso se percibió en las noticias y caricaturas políticas públicas a partir del segundo trimestre de 1959, cuando el gobierno cubano se fue perfilando como un Estado socialista e inició una serie de reformas políticas orientadas a beneficiar al pueblo por encima de los intereses extranjeros provocando de esta forma, una desconstrucción simbólica de la imagen de Fidel Castro y de la Revolución Cubana frente a la opinión pública.

\section{Bibliografía}

\section{Fuentes primarias}

El Tiempo, 1958-1959.

El País, 1958-1959.

\section{Fuentes secundarias}

Acevedo Carmona, Darío. "Política y caudillos colombianos en la caricatura editorial, 1920-1950”. Revista Historia y Sociedad. No. 17 (2009): 237-282.

Bethell, Leslie. Historia de América Latina. México y el Caribe desde 1930. Barcelona: Crítica, 1998.

Buch Rodríguez, Luis y Suárez, Reinaldo. Gobierno Revolucionario Cubano. Primeros pasos. La Habana: Editorial de Ciencias Sociales, 2009.

Burker, Peter. Visto y no visto. El uso de la imagen como documento histórico. Barcelona: Crítica, 2001.

Cacua Prada, Antonio. Historia del periodismo colombiano. Bogotá: Ediciones Sua, 1968.

Calvo González, Patricia. "El proceso revolucionario cubano desde la óptica de la dimensión pública: el papel de los medios de comunicación". (XVI Encuentro de Latinoamericanistas Españoles: Congreso Internacional. España: Universidad de Santiago de Compostela, septiembre de 2010), 1557-1576. 
Castro Ruz, Fidel. La victoria estratégica. Por todos los caminos de la Sierra. La contraofensiva estratégica. De la Sierra Maestra a Santiago de Cuba. Madrid: Ediciones Akal, S.A., 2012.

Chartier, Roger. A historia cultural: entre prática e representações. Rio de Janeiro: Difel, Bertrand Brasil, 1990.

Chartier, Roger. El mundo como representación. Estudios sobre historia cultural. Madrid: Gedisa. 2005.

Collazos González, Gina Paola. "Diseño editorial como expresión y afirmación de la ideología política, social y cultural. Casos de estudio: La Nación de Argentina y El Tiempo de Colombia" (Tesis de Maestría en Diseño. Universidad de Palermo. Facultad de Diseño y Comunicación, 2011), 53.

Egea Casas Raquel, Revolución Cubana: la represión castrista vista a través de la persecución y encierro de Reinal Arenas en la prisión del Morro. Revista Semestral de Iniciación a la Investigación en Filología. Vol. 5, (2011): 68.

Gobierno Municipal de Santiago de Cali. Decreto No. 0313, “por el cual se exalta una personalidad y se lamenta su sensible fallecimiento”. Cali, 1985. HYPERLINK “ftp://ftp.cali.gov.co/DECRETOS/1985/ DECRETO0313ABRIL1985.pdf” ftp://ftp.cali.gov.co/DECRETOS/1985/DECRETO0313ABRIL1985.pdf

Guerra, Sergio y Alejo Maldonado. Historia de la Revolución Cubana. Navarra: Edición de Txalaparta, 2009.

Habermas, Jürgen. Historia crítica de la opinión pública. México: Gili, 1994.

Hernández Fonseca, e-mail al Comandante. Caricaturas de PONG. Brasil: Editora Belém do Pará, 2006.

Hernández Mora, Salud. "El Tiempo, principal diario de Colombia, cumple sus primeros 100 años", (El Mundo, Bogotá: 23 de enero de 2011), "http://www.elmundo.es/america/2011/01/23/ colombia/1295800028.html” $\quad$ http://www.elmundo.es/ameri$\mathrm{ca} / 2011 / 01 / 23 /$ colombia/1295800028.html

204 Leal Cruz, Miguel. “Cuba en la prensa canaria 1934-1962, antecedentes y revolución” (Tesis Doctoral en Ciencias de la Información, Universidad de La Laguna, 2007), 263. 
Monereo Pérez, Manolo. Cuba, revolución social y salud pública 19591984. La Habana: Editorial Ciencias Médicas, 2008.

Rodríguez Maza, Emilio. “Castro, La Revolución Cubana y la autodeterminación de los pueblos”. Revista de Estudios Políticos. No. 124 (1962): 175-190.

Ruiz Hernández, José. Cuba, revolución social y salud pública 1959-1984. La Habana: Editorial Ciencias Médicas, 2008.

Sánchez Rebolledo, Adolfo. Fidel Castro: la Revolución Cubana 19531962, compilación de documentos y discursos de 1953 a 1962. México: Ediciones ERA S.A., 1972.

Silva León, Arnaldo. Breve historia de la Revolución Cubana. La Habana: Editorial de Ciencias Sociales-Instituto Cubano del Libro, 2003. Vallejo Mejía, Maryluz. A plomo herido, una crónica del periodismo en Colombia 1880-1980. Bogotá: Editorial Planeta, 2006.

Para citar este artículo: González Bolaños, Andrés Felipe. "La Revolución Cubana a través de la caricatura política en los periódicos El País y El Tiempo de Colombia 1958-1959", Historia Caribe Vol. XIII No. 32 (Enero-Junio 2018): 171-205. DOI: http:/ /dx.doi.org/10.15648/hc.32.2018.7 